\title{
A Homeless Bill of Rights as a New Instrument to Protect the Rights of Homeless Persons
}

\begin{abstract}
Adam Ploszka*
Homelessness as a violation of human rights - Criminalisation of homelessness Insufficient international and European protection of the rights of homeless persons - American charters of the rights of homeless persons as a source of inspiration - Model European Homeless Bill of Rights - FEANTSA - Human rights instrument - Positive and negative rights of the homeless person - Right to exit homelessness - Right to carry out practices necessary to survival within the law - Adoption and implementation of the Charter by Human Rights Cities in Spain, Slovenia and Poland - Soft law - Perspectives for the protection of the rights of homeless persons
\end{abstract}

\section{INTRODUCTION}

There is a clear trend in the development of international human rights protection, which is manifested by the creation of mechanisms to protect the rights of individuals belonging to social or ethnic groups subject to various forms of exclusion. So far, the United Nations has adopted conventions to guarantee the rights of, among others, persons belonging to racial minorities, women, children and

*PhD, Centre for Human Rights, Faculty of Law and Administration, University of Warsaw. ORCID: 〈https://orcid.org/0000-0002-9116-7679〉. The author would like to thank FEANTSA's policy officer Maria José Aldanas for her support in the work on the article, particularly for reviewing the survey carried out for the purpose of this text and assisting in reaching out to the survey participants. The author is grateful to the editor and reviewers for their helpful comments on the earlier version of this paper.

European Constitutional Law Review, 16: 601-624, 2020

(C) The Author(s) 2020 Published by Cambridge University Press on behalf of European Constitutional Law Review. This is an Open Access article, distributed under the terms of the Creative Commons Attribution licence (http://creativecommons.org/licenses/by/4.0/), which permits unrestricted re-use, distribution, and reproduction in any medium, provided the original work is properly cited. doi: $10.1017 /$ S1574019620000310 
persons with disabilities. ${ }^{1}$ For more than a decade, discussions have also been taking place on the adoption of a convention that would protect the rights of the elderly. ${ }^{2}$ This trend is accompanied by measures intended to strengthen the protection of the rights of persons experiencing poverty, including extreme poverty, which has so far led to the United Nations adopting the UN Guiding Principles on Extreme Poverty and Human Rights, a soft law instrument. ${ }^{3}$

The above developments in international law are closely correlated with the grass-roots adoption, by individual European cities, of a non-standard instrument protecting the rights of persons affected by the homelessness crisis, i.e. a Homeless Bill of Rights. These measures were adopted at the initiative of FEANTSA (the European Federation of National Organisations working with the Homeless), a European non-governmental organisation, which, together with the Abbé Pierre Foundation, developed the model Homeless Bill of Rights. ${ }^{4}$ From this point on, the FEANTSA Bill will be referred to in this paper as the Model (European) Homeless Bill of Rights.

This paper will analyse this unusual method of protecting the rights of homeless persons. This analysis comprises four parts, which correspond with the established structure of the paper. The first part focuses on a human rights-based approach to homelessness. In this part, the paper presents the European Homeless Bill of Rights against the broader backdrop of the current international human rights standard applying to persons experiencing homelessness. This perspective is adopted to enable an assessment of the potential of this human rights tool. The second part restates the motives behind the drafting of the European Homeless Bill of Rights and also describes the measures that inspired the European Bill's drafters, namely the Homeless Bill of Rights laws adopted by individual states in the United States of America. The third part examines the normative structure of the Model

${ }^{1} \mathrm{Cf}$ International Convention on the Elimination of All Forms of Racial Discrimination, adopted on 21 December 1965 (A/RES/2106(XX); Convention on the Elimination of All Forms of Discrimination against Women, adopted on 18 December 1979 (A/RES/34/180); Convention on the Rights of the Child, adopted on 20 November 1989 (A/RES/44/25); Convention on the Rights of Persons with Disabilities (CRPD), adopted on 13 December 2006 (A/RES/61/106).

${ }^{2}$ See I. Doron and I. Apter, 'International Rights of Older Persons: What Difference Would a New Convention Make to Lives of Older People?', 11 Marquette Elder's Advisor (2009) p. 367. Notably, such a Convention was adopted in the inter-American human rights system: Inter-American Convention on Protecting the Human Rights of Older Persons, adopted on 15 June 2015.

${ }^{3}$ See UN Guiding Principles on Extreme Poverty and Human Rights (A/HRC/21/39).

${ }^{4}$ The Bill includes 11 rights, the most important of which is the right to exit homelessness. The Bill of Rights not only sets out a list of rights but also defines their scope and substance. The text of the Bill is available at the website of Housing Rights Watch, 〈www.housingrightswatch.org/ sites/default/files/Template\%20Homeless\%20Bill\%20of\%20Rights\%20EN_0.pdf $\rangle$, visited 18 November 2020. 
Homeless Bill of Rights. Finally, the fourth part explores how the Bill has been adopted and implemented in local municipal jurisdictions across Europe. The process of implementation of the Bill by European cities was analysed based on data obtained from a dedicated survey form, which was completed by representatives of the adopting cities or the non-governmental organisations operating in those cities. So far, the Bill has been adopted by eight European cities - four in Slovenia, three in Spain, and one in Poland.

The main goal of this paper is to answer the research question whether the formulation and implementation of the European Model Homeless Bill, which is a very promising development, will actually be able to change the situation of people experiencing homelessness.

\section{THE STANDARD OF HUMAN RIGHTS PROTECTION OF HOMELESS PERSONS}

Homelessness is a global and borderless phenomenon. Homelessness is experienced by individuals in both wealthy OECD countries and low-income developing countries. Due to the lack of a uniform approach to defining this phenomenon, it is difficult to unequivocally determine the precise size of the population experiencing homelessness. ${ }^{5}$ According to estimates, no less than 150 million people globally (about $2 \%$ of the world's population) are affected by homelessness. ${ }^{6}$ In the European Union, at least 700,000 homeless people are sleeping rough or in emergency/temporary accommodations. ${ }^{7}$ In recent years, especially in Europe, there has been an upward trend in the number of people experiencing homelessness. ${ }^{8}$

Entities assisting the homeless in overcoming the homelessness crisis resort to various measures in their actions aimed at tackling the issue. The legal instruments employed for this purpose also include human rights measures. The latter are

\footnotetext{
${ }^{5}$ Due to difficulties in defining homelessness, the ETHOS definition of homelessness and housing exclusion was developed by the European Observatory on Homelessness. This definition, or more broadly speaking typology of homelessness and housing exclusion, can help to gather and analyse statistics on homelessness in a more consistent manner across Europe. This typology, although probably the most popular in this area, is still not universally applied. See further K. Amore et al., 'The ETHOS Definition and Classification of Homelessness: An Analysis', 5(2) European Journal of Homelessness (2011) p. 19; B. Edgar, 'The ETHOS Definition and Classification of Homelessness and Housing Exclusion', 6(2) European Journal of Homelessness (2012) p. 219.

'J. Chamie, 'As Cities Grow, So Do the Numbers of Homeless', YaleGlobal Online, 2017.

${ }^{7} \mathrm{C}$. Serme-Morin, The State of Emergency Shelters in Europe, Homeless in Europe. The Magazine of FEANTSA - The European Federation of National Organisations Working with the Homeless AISBL, Spring 2019, p. 2.

${ }^{8}$ As noted in European Parliament resolution of 16 November 2017 on combating inequalities as a lever to boost job creation and growth (2016/2269(INI)), point 60 .
} 
increasingly used by non-governmental organisations working with homeless persons. Why has the human rights-based approach to homelessness become more and more popular? One of the best answers to this question is that this approach is generally meant to strengthen other homelessness strategies and make them more effective. ${ }^{9}$ This conclusion is based on the assumption that a human rights approach to homelessness implies a shift in the perception of both the problem itself and the remedies available to address it. From a human rights perspective, the problem is no longer impersonal but one that should be perceived through the prism of human rights violations affecting the homeless. The legal empowerment of persons affected by homelessness crises is expected to lead to a situation in which these persons cease to be solely recipients of assistance from public authorities. ${ }^{10}$ Consequently, the prevention of homelessness ceases to be an act of goodwill on the part of public authorities, and its performance is no longer entirely left within the ambit of political discretion. Instead, it becomes a legal obligation subject to judicial review that may be requested in the event of non-performance or improper performance. ${ }^{11}$

To effectively invoke human rights to address homelessness, one must identify the human rights standards on the protection of homeless persons and the related responsibilities of public authorities. These standards are derived not only from constitutional laws but also from international human rights law instruments. Accordingly, an attempt is made below to briefly characterise the current state of international protection of the rights of homeless persons. A restatement of the relevant standard of human rights protection enables the assessment of the

${ }^{9}$ Such a conclusion was reached by the UN Committee on Economic, Social and Cultural Rights in the context of the human rights-based approach to tackling extreme poverty, which is closely linked to homelessness. Cf Substantive Issues Arising in the Implementation of the International Covenant on Economic, Social and Cultural Rights: Poverty and the International Covenant on Economic, Social and Cultural Rights. Statement Adopted by the Committee on Economic, Social and Cultural Rights on 4 May 2001, para. 2, E/C.12/2001/10.

${ }^{10}$ For a more extensive discussion of the legal empowerment of persons affected by homelessness or extreme poverty, see M. Nowak, 'A Human Rights Approach to Poverty', 8(1) Human Rights in Development Online (2002) p. 29; D. Banik, 'Legal Empowerment as a Conceptual and Operational Tool in Poverty Eradication', 1(1) Hague Journal on the Rule of Law (2009) p. 117.

${ }^{11}$ Concerning the human rights based approach to poverty reduction see also A. Sengupta, 'Human Rights and Extreme Poverty', Economic \& Political Weekly (2010) p. 85; R. Kanbur, 'Attacking Poverty: What is the Value Added of a Human Rights Approach?' in A.K. Sengupta et al. (eds.), Freedom from Poverty as a Human Right, vol. 3, Economic Perspectives (Paris 2010) p. 13-17; S. Osmani, 'Poverty and Human Rights: Building on the Capability Approach', 6(2) Journal of Human Development (2005) p. 205; European Network of National Human Rights Institutions, 'Applying a Human Rights-Based Approach to Poverty Reduction and Measurement A Guide for National Human Rights Institutions', 2020. In context of homelessness see P. Kenna and G.F. Evangelista, 'Applying Human Rights Based Approach to Homelessness', in S. Jones (ed.), Mean Streets: A Report on the Criminalisation of Homelessness in Europe (FEANTSA 2013) p. 31. 
impact of the European Homeless Bill of Rights as a new human rights instrument. As the Bill has been adopted by cities in Europe, the paper examines only those of the relevant standards that apply to European countries.

In this context, it should be noted that, as far as international law is concerned, the notion of the rights of persons experiencing homelessness is essentially associated with the right to housing and the related obligations of public authorities. ${ }^{12}$ However, the only legal instrument that expressly sets out public authorities' obligation to counteract homelessness is the Revised European Social Charter, ${ }^{13}$ which in its Article 31(2), entitled 'The right to housing', provides that: 'With a view to ensuring the effective exercise of the right to housing, the Parties undertake to take measures design to: prevent and reduce homelessness with a view to its gradual elimination'. ${ }^{14}$ Article 31(2) provides a basis for the extensive jurisprudence of the European Committee of Social Rights, which clarifies the obligations of public authorities arising from that provision. ${ }^{15}$

An explicit obligation to counteract homelessness and guarantee the rights of people affected by homelessness crises is not directly included among the binding legal acts that make up the universal human rights system. Only the UN Guiding Principles on Extreme Poverty and Human Rights, which, as already noted, is a non-binding instrument, directly refer to state obligations to tackle homelessness. The Guiding Principles provide that states should:

'ensure access to water and sanitation for homeless persons, and refrain from criminalizing sanitation activities, including washing, urinating and defecating in public places, where there are no adequate sanitation services available'. ${ }^{16}$

\footnotetext{
${ }^{12}$ On the right to housing $c f$, in particular, J. Hohmann, The Right to Housing: Law, Concepts, Possibilities (Bloomsbury Publishing 2013); S. Fitzpatrick and B. Watts, The 'Right to Housing' for Homeless People (Homelessness Research in Europe 2010) p. 105. It is worth noting that the right to housing was recently strengthened by recognition of the right to the city in the Habitat III New Urban Agenda. $C f$ I. Turok and A. Scheba, "Right to the City" and the New Urban Agenda: Learning from the Right to Housing', 7(4) Territory, Politics, Governance (2019) p. 494; M. Marcenko, 'International Assemblage of the Security of Tenure and the Interaction of City Politics with the International Normative Discourse', 51(2) The Journal of Legal Pluralism and Unofficial Law (2019) p. 151.

${ }^{13}$ CETS 163 - European Social Charter (Revised).

${ }^{14}$ Given the specific normative nature of the European Social Charter, which allows states to choose the provisions they are willing to accept as binding legal obligations, it should be noted that less than half of the 34 states that have ratified this instrument have opted to be bound by this provision.

${ }^{15} \mathrm{Cf}$, in particular, European Committee of Social Rights decisions on merits in Centre on Housing Rights and Evictions (COHRE) v Italy, No. 58/2009; European Federation of National Organisations Working with the Homeless (FEANTSA) v France, No. 39/2006; European Roma Rights Centre v Bulgaria, No. 31/2005.

${ }^{16}$ Principle no. 78.
} 
The Guiding Principles also oblige states to accord priority to the eradication of homelessness through a national strategy, while allocating sufficient resources to the provision of adequate transitional shelter to all homeless persons. ${ }^{17}$ The latter obligation is essential for the public debate on homelessness. Homeless persons usually focus their attention on fulfilling their everyday needs, rather than on actions related to local or national politics. The homelessness problem usually appears on the fringes of public debate.

The International Covenant on Economic, Social and Cultural Rights is a key instrument for the universal protection of the human rights of homeless persons. Although the Pact does not make any direct reference to homelessness, its Article 11 guarantees the right to an adequate standard of living, which includes the right to housing. While interpreting this article in its general comments, the UN Committee on Economic, Social and Cultural Rights noted several state obligations related to counteracting homelessness.

An important starting point for determining what actions the state should take to counteract homelessness is to identify the statistical severity of the problem. Access to fact-based evidence is essential, for example, to a proper assessment of whether funds spent to tackle homelessness adequately correspond to the size of the homeless population. For this reason, the Committee emphasised that the obligation to ascertain the full extent of homelessness and inadequate housing within its jurisdiction should have immediate effect. ${ }^{18}$ The growing size of the homeless population is also reflected by the Committee's recommendation that this way, the Committee indirectly noted the need for the legal empowerment of homeless persons.

In the Committee's opinion, the necessity of addressing homelessness is also expressed by the state's obligation to prevent an individual at risk of homelessness from becoming homeless, especially in the event of forced eviction: 'it would also be appropriate to explore the possibility of facilitating class action suits in situations involving significantly increased levels of homelessness. ${ }^{19}$ In this context, the Committee stated that:

'Evictions should not result in individuals being rendered homeless or vulnerable to the violation of other human rights. Where those affected are unable to provide for themselves, the State party must take all appropriate measures, to the maximum of its available resources, to ensure that adequate alternative housing, resettlement or access to productive land, as the case may be, is available..20

${ }^{17}$ Principle no. 80.

${ }^{18}$ CESCR General Comment No. 4: The Right to Adequate Housing (Art. 11 (1) of the Covenant), E/1992/23, p. 13.

${ }^{19}$ Ibid., p. 17.

${ }^{20}$ CESCR General Comment No. 7: The right to adequate housing (Art.11.1 of the International Covenant on Economic, Social and Cultural Rights: forced evictions), E/1998/22, p. 16. 
Finally, the Committee also referred to the rights of homeless people in the context of the right to water, pointing out that homeless persons should have access to properly maintained water facilities. ${ }^{21}$

The right to housing is crucial for tackling homelessness. However, it would be highly inadequate to view homelessness solely in terms of the right to housing. The experience of homelessness very often coincides with violations of several rights other than the right to housing. This issue has been highlighted in the Report of the Special Rapporteur on adequate housing as a component of the right to an adequate standard of living, and on the right to non-discrimination in this context, entitled: 'Homelessness as a global human rights crisis that demands an urgent global response'. ${ }^{22}$ This document leaves little doubt that homelessness is a violation of the rights to adequate housing and non-discrimination as well as a violation of the rights to life, personal security, health, protection of home and family, and freedom from cruel and inhuman treatment. ${ }^{23}$

This fact has also been recognised to some extent by the UN Committee on Economic, Social and Cultural Rights in its interpretation of the prohibition against discrimination. As the Committee declared,

'Individuals and groups of individuals must not be arbitrarily treated on account of belonging to a certain economic or social group or strata within society. A person's social and economic situation when living in poverty or being homeless may result in pervasive discrimination, stigmatization and negative stereotyping which can lead to the refusal of, or unequal access to, the same quality of education and health care as others, as well as the denial of or unequal access to public places. ${ }^{24}$

Despite the obvious conclusion that homelessness is inextricably linked with violations of several human rights, the phenomenon remains on the fringes of jurisprudential activity (broadly understood) and other forms of expression of

${ }^{21}$ CESCR General Comment No. 15: The Right to Water (Arts. 11 and 12 of the International Covenant on Economic, Social and Cultural Rights), E/C.12/2002/11, p. 16c.

${ }^{22}$ Report of the Special Rapporteur on adequate housing as a component of the right to an adequate standard of living, and on the right to non-discrimination in this context: Homelessness as a global human rights crisis that demands an urgent global response, $\mathrm{A} / \mathrm{HRC} / 31 / 54$.

${ }^{23}$ Nevertheless, it is worth noting that this issue has previously been addressed from a human rights perspective. $C f$, in particular, P. Lynch and J. Cole, 'Homelessness and Human Rights: Regarding and Responding to Homelessness as a Human Rights Violation', 4 Melbourne Journal of International Law (2003); M. Foscarinis, 'Homelessness and Human Rights: Towards an Integrated Strategy', 19 Saint Louis University Public Law Review (2000).

${ }^{24}$ CESCR General Comment No. 20 Non-discrimination in economic, social and cultural rights (Art. 2, para. 2 of the International Covenant on Economic, Social and Cultural Rights), E/C.12/ GC/20, p. 35. See also M. Thornton, 'Social Status: The Last Bastion of Discrimination', 1(3) AntiDiscrimination Law Review (2018). 
bodies responsible for upholding civil and political rights and freedoms. There are many reasonable explanations for that fact. One possible explanation is that persons affected by homelessness crises tend to demonstrate a low level of interest in legal activism, as they would rather focus on activities aimed at providing themselves with a means of survival. Another reason could be the insufficient number of non-governmental organisations that resort to the legal avenues of counteracting homelessness. ${ }^{25}$ Whatever the causes are, the effect is that homelessness and the rights of the homeless are virtually absent from the General Comments of the Human Rights Committee issued in connection with the application of the International Covenant on Civil and Political Rights. The Committee has only referred explicitly to homelessness in the context of the right to elections, indicating that 'States must take effective measures to ensure that all persons entitled to vote are able to exercise that right. Where registration of voters is required, it should be facilitated and obstacles to such registration should not be imposed. If residence requirements apply to registration, they must be reasonable, and should not be imposed in such a way as to exclude the homeless from the right to vote'. ${ }^{26}$ By and large, the phenomenon of homelessness is also rarely explicitly addressed in the case law of the European Court of Human Rights. ${ }^{27}$

In summary, the rights of homeless persons have not been specifically dealt with by an instrument of international law in the form of an international human rights agreement applicable to European countries. The occasional references to homelessness or the rights of homeless persons in legislation or the practices of regulatory bodies are essentially linked to the right to housing. Notably, the right to housing is a social right. Despite efforts to change this state of affairs, ${ }^{28}$ the right

\footnotetext{
${ }^{25}$ However, it is worth mentioning that over decades, especially on the domestic level, there were ample strategic litigation proceedings related to homelessness. $C f$ G.L. Blasi, 'Litigation on behalf of the Homeless: Systematic Approaches', 31 Washington University Journal of Urban \& Contemporary Law (1987) p. 137; L.S. Dakin, 'Homelessness: The Role of the Legal Profession in Finding Solutions Through Litigation', 21(1) Family Law Quarterly (1987) p. 93; B.S. Waxman, 'Fighting the Criminalization of Homelessness: Anatomy of an Institutional Anti-Homeless Lawsuit', 23 Stetson Law Review (1993); M. Foscarinis and R. Herz, 'The Criminalization of Homelessness: An Overview of Litigation Theories and Strategies', 29 Clearinghouse Review (1995).

${ }^{26}$ General Comment No. 25: The right to participate in public affairs, voting rights and the right of equal access to public service (Art. 25); 12/07/96, CCPR/C/21/Rev.1/Add.7.

${ }^{27}$ See ECtHR 21 January 2011, No. 30696/09, M.S.S. v Belgium and Greece; ECtHR 17 October 2013, No. 27013/07, Winterstein and Others v France; ECtHR 24 April 2012, No. 25446/06, Yordanova and others v Bulgaria; ECtHR 20 October 2015, No. 40378/10, Fazia Ali $\mathrm{v}$ the United Kingdom. See also A. Remiche, 'Yordanova and others v Bulgaria: The Influence of the Social Right to Adequate Housing on the Interpretation of the Civil Right to Respect for one's Home', 12(4) Human Rights Law Review (2012) p. 787.

${ }^{28} \mathrm{Cf}$, in particular, adoption of an Optional Protocol to the International Covenant on Economic, Social and Cultural Rights, United Nations, Treaty Series, vol. 999, p. 171.
} 
to housing as a social right enjoys a substantially lower level of protection in comparison with personal and political rights and freedoms. At the same time, the practice of exercising the right to housing across European jurisdictions raises serious concerns. ${ }^{29}$

Because of these circumstances, persons experiencing homelessness crises are less able to invoke human rights. In consequence, crucial importance is attached to the human rights standards, applicable to everyone, which are applied to the situation of homeless persons.

\section{A BILL OF RIGHTS AS A WAY TO OPPOSE THE CRIMINALISATION OF HOMELESSNESS - THE AMERICAN EXPERIENCE}

Despite the above, the key rationale behind the development of the European Homeless Bill of Rights was not the absence (or difficulties in the identification) of adequate standards on the protection of the human rights of homeless persons. A central goal of the Bill was to oppose the criminalisation of homelessness, ${ }^{30}$ a policy trend present in several European countries. ${ }^{31}$ This notion comprises all legislation that establishes criminal penalties for various forms of use of public space such as begging or foraging or that allows the installation of 'defensive' public architecture that prevents, for example, sleeping on benches. The criminalisation of homelessness is becoming increasingly common, ${ }^{32}$ as demonstrated by the fact that the UN Guiding Principles on Extreme Poverty and Human Rights specify that 'Homeless persons in particular are frequently subject to restrictions on their freedom of movement and criminalized for using public space'. ${ }^{33}$ The criminalisation of homelessness does not help solve the problem of homelessness; rather, it constitutes an attempt to hide the phenomenon from the public eye.

${ }^{29}$ D. Mijatović, The Right to Affordable Housing: Europe's Neglected Duty (Strasbourg 23 January 2020), 〈www.coe.int/en/web/commissioner/-/the-right-to-affordable-housing-europe-s-neglectedduty $\rangle$, visisted 18 November 2020.

${ }^{30} \mathrm{Cf}$, more concerning criminalisation of homelessness: J. Waldrom, 'Homelessness and the Issue of Freedom', 39 UCLA Law Review (1991) p. 295, D. Mitchell, The Right to the City: Social Justice and the Fight for Public Space (Guildford Press 2003); M. Foscarinis et al., 'Out of Sight - Out of Mind: The Continuing Trend toward the Criminalization of Homelessness', 6 Georgetown Journal on Poverty Law and Policy (1999) p. 145, P.J. Fischer, The Criminalization of Homelessness (Springer 1992) p. 57.

${ }^{31}$ FEANTSA, Advocating for the rights of homeless people. User Guide. A handbook for social actors to engage with the Homeless Bill of Rights, p. 1.

${ }^{32}$ See Report of the Special Rapporteur on extreme poverty and human rights: The Penalization of Poverty, A/66/265; S. Jones (ed.), Mean Streets: A Report on the Criminalisation of Homelessness in Europe (Brussels 2013).

${ }^{33}$ UN Guiding Principles on Extreme Poverty and Human Rights, principle No. 65. 
The most extreme form of criminalisation of homelessness is the measures adopted in Hungary, where a homeless person's refusal to accept the support offered by public authorities can even directly lead to deprivation of liberty. ${ }^{34}$

The European Parliament has also spoken on the criminalisation of homelessness, adopting a resolution on EU homelessness strategy in 2014. In this instrument, the EU member states are called upon immediately to put an end to the criminalisation of homeless people and to change the discriminatory practices used to prevent homeless people from accessing social services and shelter. ${ }^{35}$

Homelessness has also been criminalised outside Europe, with the phenomenon occurring, with varying degrees of intensity, in non-European countries, especially the United States of America. ${ }^{36}$ It is the USA where the idea of the Homeless Bill of Rights originally emerged as a tool for counteracting the practice of criminalising homelessness, and further as an instrument for preventing discrimination against and the social exclusion of people affected by homelessness crises, and improving homeless persons' access to justice. ${ }^{37}$ Such legislation was first adopted by an unincorporated territory of the United States, Puerto Rico, ${ }^{38}$ in 2007, and then by several states: Rhode Island ${ }^{39}$ (2012), Connecticut ${ }^{40}$ (2013) and Illinois ${ }^{41}$ (2013). Furthermore, California, Hawaii, Oregon, Vermont, Missouri and Massachusetts have made attempts, albeit unsuccessful, to adopt the Homeless Bill of Rights. ${ }^{42}$

The adopted texts of the Homeless Bill of Rights reveal two regulatory models. The dominant model is based on the Rhode Island Bill, which was subsequently more or less reproduced and adopted by Connecticut and Illinois, with Puerto Rico adopting a different regulatory model.

\footnotetext{
${ }^{34}$ See UN Special Rapporteur on adequate housing as a component of the right to an adequate standard of living, and on the right to non-discrimination in this context open letter to the Government of Hungary, 20 June 2018, OL HUN 4/2018.

${ }^{35}$ European Parliament resolution of 16 January 2014 on an EU homelessness strategy, (2013/ 2994(RSP)), point 14.

${ }^{36}$ See National Law Center on Homelessness \& Poverty, Report: Housing Not Handcuffs: Ending the Criminalization of Homelessness in U.S. Cities, 2018.

${ }^{37}$ See S.K. Rankin, 'A Homeless Bill of Rights (Revolution)', 45(2) Seton Hall Law Review (2015) p. 384; M.F. Drywa Jr., 'Rhode Island's Homeless Bill of Rights: How Can the New Law Provide Shelter from Employment Discrimination?', 19(3) Roger Williams University Law Review (2014) p. 716; J. Sheffield, 'A Homeless Bill of Rights: Step by Step from State to State', 19(1) Public Interest Law Reporter (2013) p. 8.

${ }^{38}$ Act No. 130, 15th Leg., 6th Sess. (P.R. 2007).

${ }^{39}$ An Act Relating To Property - Rhode Island Fair Housing Practices Act, Chapter 37.1 Homeless Bill of Rights.

${ }^{40}$ An Act Concerning a Homeless Person's Bill of Rights, 2013 Conn. Pub. Acts 13-251.

${ }^{41}$ State of Illinois Public Act 098-0516 An Act in relation to homeless persons.

${ }^{42}$ See National Law Center on Homelessness \& Poverty, Report: From Wrongs to Rights: The Case for Homeless Bill of Rights Legislation
} 
According to the first model, based on the Rhode Island Homeless Bill of Rights, the rights enshrined in the Bill are an interpretation of the principle of equality and non-discrimination applied in the context of homeless persons. This view is confirmed by the opening clause of the Rhode Island Bill,whose language leads to the conclusion that the Bill does not grant any new rights to people affected by homelessness crises, according to the clause in question:

'No person's rights, privileges, or access to public services may be denied or abridged solely because he or she is homeless. Such a person shall be granted the same rights and privileges as any other resident of this state'.

Under the Rhode Island Bill, homeless persons are afforded seven rights:

1. the right to use and move freely in public spaces in the same manner as any other person;

2. the right to equal treatment by all state and municipal agencies;

3. the right not to face discrimination while seeking or maintaining employment due to his or her lack of permanent mailing address, or his or her mailing address being that of a shelter or social service provider;

4. the right to emergency medical care free from discrimination based on his or her housing status;

5. the right to vote, register to vote, and receive documentation necessary to prove identity for voting without discrimination due to his or her housing status;

6. the right to protection from disclosure of his or her records and information provided to homeless shelters and service providers to state, municipal and private entities without appropriate legal authority;

7. the right to a reasonable expectation of privacy in his or her personal property to the same extent as personal property in a permanent residence.

Importantly, persons affected by homelessness crises can enforce their rights under the Bill directly through court action. The Bill explicitly allows this by providing that 'In any civil action alleging a violation of this chapter, the court may award appropriate injunctive and declaratory relief, actual damages, and reasonable attorneys' fees and costs to a prevailing plaintiff. It is worth mentioning that this type of guarantee is not included in the Bill adopted by Connecticut.

The other regulatory model, used by Puerto Rico, represents a different approach. The Puerto Rico Homeless Bill of Rights forms a part of a wider and well-established legislative framework for the tackling of homelessness (Act 130). ${ }^{43}$ The purpose of this legislation is defined, in a very ambitious way, as to 'make Puerto Rico a place where all human beings have a roof over their heads, and prompt and sensitive access to the basic services every human being is entitled to receive'.

${ }^{43}$ See previously Act No. 250 of 18 August 1998. 
A key element of this approach is the establishment of an administrative mechanism, i.e. the creation of a Multi-Sector Homeless Population Support Council. The Council is tasked with, among other things, implementing the rights of persons affected by homelessness crises. The Council's membership includes representatives of persons experiencing homelessness and non-governmental organisations working for homeless persons. The Declaration of the Rights of the Homeless, which is a part of this legislative framework, recognises not only negative rights, a common feature of the bills modelled after the Rhode Island Homeless Bill of Rights, but also positive rights, such as the right to shelter, food, medical care and vocational training. It should be noted that the rights guaranteed by the Puerto Rico Homeless Bill of Rights cannot be enforced through court action. This is because the Bill provides that 'all complaints instituted under the provisions of this chapter shall be processed as provided by the regulations to be approved to that effect in compliance with Uniform Administrative Procedures Act of the Commonwealth of Puerto Rico'.

In the USA, the fundamental importance of the state legislation adopting a Homeless Bill of Rights comes to light when compared to the absence of the protection of social rights, including the right to housing, which is crucial for preventing homelessness, at the federal constitutional level. Moreover, the United States of America has not ratified the International Covenant on Economic, Social and Cultural Rights. Consequently, homeless persons in the USA do not have the opportunity to challenge, at the federal or international level, the nonfulfilment of the right to housing by public authorities. Given the above, the efforts aiming to ensure the legal protection of the right to housing (and other social rights) focus on seeking remedies based on an interpretation of the equality clause. The adoption of a Homeless Bill of Rights at the state level is, in fact, an example of such efforts.

\section{The Model Homeless Bill of Rights}

The American experience was clearly a source of inspiration for the development of a draft of the European Homeless Bill of Rights, a joint project of FEANTSA and the French non-governmental organisation Abbé Pierre Foundation. Apart from the similarities revealed by a comparison of the list of rights covered by the Bill, this inspiration becomes evident in the preamble to the Bill, which reads:

\footnotetext{
'To help achieve this, the Council believes that it is important to re-state that every person who is experiencing homelessness is entitled to the same treatment as any other resident in the city area. No one should be denied further rights because they are homeless. ${ }^{44}$
}

${ }^{44}$ Supra n. 4. 
The drafters of the European Bill envisaged that it would guarantee the fundamental rights of persons living on the streets. ${ }^{45}$ Unlike the American bills, the European instrument was created for local, rather than central (national), authorities. The drafters justified this approach primarily by pointing out that it is local authorities who are able to enact local laws resulting in the criminalisation of homelessness, a process that the Bill is supposed to prevent. This choice is further justified by another factual consideration, namely the fact that most European jurisdictions generally oblige local authorities to prevent homelessness. ${ }^{46}$ Last but not least, designating local authorities as the audience of the Homeless Bill of Rights can be justified for utilitarian reasons: it is much easier to persuade a European city to adopt the Bill than to convince a national government to guarantee rights for homeless persons by changing a country's constitutional order.

Defining the Bill as an instrument to be adopted and implemented by local authorities is not, however, without certain ramifications, the most important being the requirement that a locally adopted Homeless Bill of Rights must comply with higher-ranking legal enactments, especially those of the constitutional rank, which is a consequence of the hierarchical system of sources of law prevailing across Europe. This means that whenever homelessness is criminalised at a national level, the goal of decriminalising homelessness cannot be achieved in the short term. However, it cannot be ruled out that the pressure generated by the adoption of the Homeless Bill of Rights at the municipal level could lead to this goal being achieved in the long term. Another obvious consequence of designating cities as the addressees of the Bill is the fact that the instrument's scope of impact is limited to municipalities that decide to adopt it. This also implies a reduction in the financial resources that can be allocated to the implementation of a Bill, as city budgets are much lower than those of national governments.

The Homeless Bill of Rights was launched in 2016, which is relatively recent. It includes eleven rights:

1. Right to exit homelessness;

2. Right to access to decent emergency accommodation;

3. Right to use public space and to move freely within it;

4. Right to equal treatment for all, without discriminating against those who do not have a home;

5. Right to an effective postal address;

6. Right to access basic sanitary facilities;

7. Right to emergency services;

8. Right to vote;

${ }^{45}$ FEANTSA, User Guide, supra n. 31, p. 4.

${ }^{46}$ I. Baptista et al. (eds.), Local Connection Rules and Access to Homelessness Services in Europe: EOH Comparative Studies on Homelessness No. 5 (FEANTSA, 2015). 
9. Right to data protection;

10. Right to privacy;

11. Right to carry out practices necessary to survival within the law.

The European Homeless Bill of Rights not only sets out a list of rights but also defines their scope and substance. Individual provisions of the Bill give the impression that they generally follow the model established in the Rhode Island Homeless Bill of Rights, emphasising that homeless persons should be treated equally to others and not discriminated against. ${ }^{47}$ A key difference is that the European Bill includes not only 'classic' negative rights but also positive rights. These rights can only be guaranteed if action is taken by the bodies responsible for upholding them, in this case - cities. ${ }^{48}$ Attention should be paid in particular to the right to exit homelessness, which is stated at the outset of the Bill. This right derives from the housing paradigm, an increasingly popular perspective in the context of homelessness prevention. The housing paradigm is based on the correct observation that a whole range of aid measures implemented by national or local governments that do not lead to a homeless person obtaining accommodation will only alleviate homelessness rather than aim to solve the problem. The above right is associated with the second right laid down in the European Bill, namely the right to access to decent emergency accommodation. The first of these rights is a programmatic norm expressed by the imperative expression 'shall work', which is characteristic of the normative structure of a social right. The second right sets out an obligation with immediate effect, as evidenced by the phrase 'must be accessible to all people who are homeless'. Among other positive rights provided for by the Bill, one should also note the right to an effective postal address. The relevance of this right becomes particularly, and perhaps exclusively, apparent in the case of homeless persons. This right is fundamental to the exercise of other rights closely linked to access to courts or other administrative bodies for individuals affected by homelessness crises. Such access is substantially restricted for a person without a postal address. ${ }^{49}$

A comparison of the rights guaranteed by the European Homeless Bill of Rights and the Rhode Island Homeless Bill of Rights reveals that the former does

\footnotetext{
${ }^{47}$ See also S. Atrey, 'The Intersectional Case of Poverty in Discrimination Law', 18(3) Human Rights Law Review (2018) p. 411.

${ }^{48}$ It should be noted, by the way, that in the preamble of the Bill, the responsibility for tackling homelessness is defined in much broader terms, with the Bill reading ' $(\ldots)$ we believe it is the responsibility of all individuals, businesses and organisations, and of all local authorities, including our city authority, to maximize their contribution to improving the living conditions of people who are homeless, and to lessen the negative effects of homelessness'.

${ }^{49}$ See G. Byrne, The Postal Paradox: How Having No Address Keeps People Homeless (Citizens Advice).
} 
not refer to discrimination in employment or access to employment. This absence has a twofold explanation, the first being that an extensive body of anti-discrimination legislation exists at the EU level, thus making a repetition of the relevant norms in the Bill redundant. The second points to a cultural difference, namely the fact that work is not perceived as a key element of exiting homelessness.

Drafters of the Bill designed it as a compilation of fundamental rights taken from European and international human rights instruments, which have subsequently been adapted to the specific situation of homeless persons. ${ }^{50}$ In this context, it is somewhat surprising that the Bill does not refer to the dignity of the homeless individual, particularly given that homelessness is quite often accompanied by violations of dignity. The only explicit reference to 'dignity' that appears in the Bill relates to the substance of the right to access basic sanitary facilities. However, human dignity should not be reduced to this aspect alone. Human dignity, as a right or a legal principle, holds a crucial position in most European legal systems. It is the source of further guarantees of rights and freedoms, including, for some jurisdictions, the right to lead a dignified life. ${ }^{51}$

The second surprising aspect is that the category of 'freedoms' has been completely omitted from the list of rights, probably due to a desire to use the notion of 'rights' in a consistent manner. This choice means that the target audience of the Bill may experience certain difficulties in establishing a relationship between the rights laid down in the Bill and binding human rights standards. This is particularly evident in the case of the right to use public space and move freely within it. This right might as well be named 'freedom of movement'. Such an expression would clearly designate a normative source of this right, namely Article 2 of Protocol 4 to the European Convention on Human Rights. ${ }^{52}$ As a side note, the Special Rapporteur on the human rights to safe drinking water and sanitation pointed to the positive obligations of public authorities arising from this freedom. In the Special Rapporteur's opinion, in situations where public spaces are utilised as dwellings, for instance by people who are homeless, states are

${ }^{50}$ FEANTSA, User Guide, supra n. 31, p. 4.

${ }^{51}$ See E. Grant, 'Dignity and Equality', 7(2) Human Rights Law Review (2007) p. 299; I.T. Winkler and C. Mahler, 'Interpreting the Right to a Dignified Minimum Existence: A New Era in German Socio-Economic Rights Jurisprudence?', 13(2) Human Rights Law Review (2013) p. 388, E.S. Tanasescu, 'Human Dignity and the Circumstantial Protection of Social Rights', in M. Zubik (ed.), Human Rights in Contemporary World Essays in Honour of Professor Leszek Garlicki (Warsaw 2016) p. 306; A. Ploszka, 'The Right to Subsistence Minimum and Its Role in the Protection of People Living in Extreme Poverty - the Polish Experience', 24 Comparative Law Review (2018) p. 225.

${ }^{52} \mathrm{See}$ Protocol No. 4 to the Convention for the Protection of Human Rights and Fundamental Freedoms, securing certain rights and freedoms other than those already included in the Convention and in the first Protocol thereto, ETS no. 046. 
also obliged to ensure a level of access that is adequate to fulfil domestic needs, including cleaning property and clothes and preparing food. ${ }^{53}$ Finally, as far as freedoms are concerned, it is difficult to understand why the list of the rights guaranteed by the Bill does not include the freedom from inhuman and degrading treatment, which is closely linked to the criminalisation of homelessness. It is worth mentioning that it is the above-mentioned freedom that is violated by the criminalisation of homelessness according to the UN Human Rights Committee. ${ }^{54}$

The European Homeless Bill of Rights is designed to be a model regulation that can be freely modified to suit the needs of cities that choose to adopt it. ${ }^{55}$ This approach has an unquestionable advantage: the Bill can be adapted to meet the requirements of a specific national legal system as well as those of local municipal law. Furthermore, the final language of a 'localised' Bill can take into account rights other than those indicated in the European Homeless Bill of Rights. Thanks to being so adaptable, the Bill can be more easily adopted by individual cities. On the other hand, one should acknowledge that this flexibility must be subject to certain limits. In particular, if the wording of a locally adopted Bill were modified to exclude key rights contained in Articles I and II of the European Homeless Bill of Rights, namely the right to exit homelessness and the right to decent emergency accommodation, such a modification would contradict the essence of the Bill.

\section{IMPLEMENTATion OF the Homeless Bill of Rights by European Cities}

Given the model nature of the European Homeless Bill of Rights, key importance should be attached to the form in which it has been adopted by individual cities. The process of implementation of the Bill by European cities was analysed based on data obtained from a dedicated survey form, which was completed by representatives of the adopting cities or non-governmental organisations operating in those cities. ${ }^{56}$ So far, the Bill has been adopted by eight European cities. Barcelona

\footnotetext{
${ }^{53}$ Report of the Special Rapporteur on the human rights to safe drinking water and sanitation: Human rights to water and sanitation in spheres of life beyond the household with an emphasis on public spaces, $\mathrm{A} / \mathrm{HRC} / 42 / 47$, point 36.

${ }^{54}$ See Human Rights Committee 'Concluding observations on the fourth periodic report of the United States of America', CCPR/C/USA/CO/4, point 19.

${ }^{55}$ FEANTSA, User Guide, supra n. 31, p. 4.

${ }^{56}$ The survey forms were completed by: Coordinator of the Barcelona's Plan for Fighting Homelessness; Director of Social Welfare and Social Services of the city Móstoles; Former external legal adviser of the Local Government of Santiago de Compostela (Galicia, Spain); Coordinator for the Implementation of the Homeless Bill of Rights, Municipal Family Assistance Centre in Gdańsk, legal officer of Brighton \& Hove Housing Coalition (a non-governmental organisation) and a representative of the Slovenian non-governmental organisation Društvo za pomoč in samopomoč brezdomcev Kralji ulice. I would like to express my heartfelt thanks to each of them.
} 
(Spain) ${ }^{57}$ was the first city in Europe to adopt the Bill in 2016, followed by four Slovenian municipalities: Maribor, ${ }^{58}$ Slovenj Gradec, ${ }^{59} \mathrm{Kranj}^{60}$ and Murska Sobota. ${ }^{61}$ Later on, in 2018, the Bill was enacted by another two Spanish cities: Santiago de Compostela ${ }^{62}$ and Móstoles. ${ }^{63}$ The Bill was most recently adopted by the Polish city of Gdańsk, ${ }^{64}$ in 2020. A city in the United Kingdom, Brighton, is close to adopting the Bill. For this reason, Brighton was covered by the survey despite the absence of formal adoption of the Homeless Bill of Rights.

Analysis of the collected data reveals two model approaches that determine the path leading to the adoption of the Homeless Bill of Rights. The first involves adoption not preceded by in-depth discussion, which would otherwise take into account the voices of persons affected by homelessness crises. Here, the Bill is treated as a starting point for the city's further actions to counter homelessness. This approach, used by the Spanish and Slovenian cities, has led to the relatively quick adoption of the Bill.

The other approach results in the Bill being adopted as a result of a participatory, multi-stakeholder implementation process, which also involves directly concerned actors, i.e. persons affected by homelessness crises. This participatory approach model was embraced by Gdańsk and is currently being followed by Brighton. Employing the participatory model approach in adopting a Bill obviously makes the process more time-consuming compared to a purely 'political' adoption process. On the other hand, this approach seems to be the most closely aligned with the human rights perception of homelessness. The approach in question is centred around the participation of homeless persons.

Among the cities enacting the Homeless Bill of Rights, only Gdańsk has adopted the instrument in a participatory way. In brief, the process employed by Gdańsk unrolled as follows. First of all, the Gdańsk City Council enacted the 2018-2023 Municipal Strategy for the Tackling of the Homelessness Problem, which provided a basis for developing an implementation path for the Homeless Bill of Rights. As part of the implementation of this strategy, seven consultative meetings were held to discuss how the Bill should be adopted. These meetings were attended by representatives of all stakeholders concerned with municipal policies on homelessness: the National Police, Municipal Police,

\footnotetext{
${ }^{57}$ The Bill was adopted on 9 May 2016.

${ }^{58}$ The Bill was adopted on 23 December 2016.

${ }^{59}$ The Bill was adopted on 1 December 2016.

${ }^{60}$ The Bill was adopted on 26 October 2016.

${ }^{61}$ The Bill was adopted on 27 December 2016.

${ }^{62}$ The Bill was adopted on 20 December 2018.

${ }^{63}$ The Bill was adopted on 26 January 2018.

${ }^{64}$ The Bill was adopted on 27 February 2020.
} 
municipal bodies dealing with homelessness, non-governmental organisations working with homeless persons and, last but not at all least, the very people concerned - the Gdańsk homeless community. The last stakeholder group was consulted by way of a survey conducted among 74 persons affected by homelessness crises. This survey has shown that the provisions of the Bill were comprehensible and satisfied the expectations of homeless persons.

Notwithstanding the differences in the processes leading to their adoption, all Homeless Bills of Rights enacted so far are, legally speaking, non-binding instruments. The Bill currently being debated in Brighton will also be nonbinding. The rights enshrined in the instruments adopted in Europe cannot, therefore, be enforced in court. Given the above, they remain, by and large, political guidelines. In most cases, the adoption of a Bill was not followed by changes to local laws by the cities concerned. It was only in the case of Santiago de Compostela that local laws were amended to decriminalise begging as part of the Bill's pre-adoption process. In Barcelona, on the other hand, due to the lack of political will to change the local law criminalising homelessness (no majority in the city council), municipal authorities changed how the existing law was applied. The local municipal police were instructed not to enforce laws criminalising homelessness.

In the majority of cities, the language of the adopted Bill closely follows the wording of the Model Homeless Bill of Rights translated into the local language. In this respect, a certain linguistic convention applied by Gdańsk should be noted with appreciation. The Gdańsk Homeless Bill of Rights uses two alternate terms, 'person experiencing homelessness' (osoba doświadczająca bezdomności) and 'person affected by a homelessness crisis' (osoba w kryzysie bezdomności), which replace the commonly appearing 'homeless person(s)' or 'the homeless'. This change is intended to emphasise the transient nature of homelessness and move away from the stereotypical and stigmatising term 'homeless person'. ${ }^{65}$

The list of rights presented in the Model Homeless Bill of Rights did not arouse much controversy in the processes leading to the adoption of individual instruments. The exception was the right specified in Article XI of the Model Homeless Bill of Rights, namely the right to carry out practices necessary to survival within the law. The provision in question raised controversies in Santiago de Compostela, Gdansk and Brighton. In all these cities, manifestations of a practice necessary to survival - begging - were or are forbidden by law. In Santiago de Compostela, the prohibition against begging was imposed locally (and was abolished during the adoption process), but both in Gdańsk

\footnotetext{
${ }^{65}$ The wording of the Gdańsk Bill is based on the Polish translation of the European Bill by Adam Ploszka.
} 
and Brighton the ban resulted from national legislation. For this reason, the Bill adopted by Gdańsk uses amended wording for Article 11, replacing the original language of the Model Bill with the following: 'Striving to ensure that nobody is forced to engage in such activities, we recognise that these practices should not be criminalized in their own right'. This normative strategy avoided a conflict between the wording of the Bill and universally applicable law. The Gdańsk Bill's Article 9, which concerns personal data, was also rephrased; the original wording of the model Article IX was entirely avoided because of concerns about its compliance with the universally applicable law based on the EU data protection legislation. Ultimately, Article 9 of the Gdańsk Homeless Bill of Rights reads as follows: 'The right to the protection of personal data under applicable laws'.

Among the rights enshrined in the Model Homeless Bill of Rights, another two provisions have evoked a discussion in the process of the Bill's implementation into local legal systems. In Brighton, Article III (the right to use public space) raised controversy, while in Santiago de Compostela, there were concerns about Article V (the right to an effective postal address). In both cases, the concerns about these articles, voiced in public debate in those cities, were based on the fear of them being interpreted as the city's approval of the anti-social attitudes of people experiencing homelessness. In an attempt to dispel this fear, it was argued that the provisions in question played an important role in counteracting the social stigmatisation of homeless persons and that generalisations in describing the attitudes of homeless persons should be avoided.

In the context of the controversy that has emerged in the process of adopting the Bill at the municipal level, one particular circumstance should be mentioned. Usually, discussions on social rights are accompanied by deliberations on the costs associated with the implementation of those rights. As far as the discussion on the Bill is concerned, no argument about costs has been raised, although the Bill contains not only civil and political rights but also social rights. Perhaps the absence of such arguments was a result of municipal policy actors realising that the rights of homeless persons, just like any other rights, entail that the community must necessarily incur certain costs. On the other hand, this assumption may turn out to be too far-reaching. The lack of controversy about the financing of the implementation of the rights guaranteed by a Bill could simply be due to the instrument's non-binding status, meaning that it does not generate any costs that would otherwise be incurred by public authorities on account of their obligation to exercise legal rights guaranteed by the Bill.

None of the Bills adopted so far has extended or reduced the list of rights conferred by the model regulation. In this context, interesting ideas have been included in the proposed Bill to be adopted by the city of Brighton, i.e. guaranteeing two additional rights to homeless persons. The first, the right to 
private possessions, ${ }^{66}$ was called for directly by homeless persons as part of the consultation process preceding the adoption of the Bill. The other is the right to life. ${ }^{67}$

It can be assumed that the adoption of the Homeless Bill of Rights should not be the end, but rather the beginning, of the process of legal empowerment of homeless persons. However, in many of the cities that have adopted the Bill, this has not happened. As the Bill has nowhere been awarded a legally binding status that would allow it to be invoked before the courts, its implementation has only remained purely political. Moreover, in the case of the Slovenian cities, not even the political process of the Bill's implementation has been undertaken.

It is worth noting at this point that various cities have taken different approaches to the implementation process. In Móstoles, the implementation of the Bill is regularly monitored by a municipal homelessness board, which is tasked with the monitoring of the Bill's practical application. An interesting approach to the implementation of the Bill has been taken in Santiago de Compostela, which involved setting up a special body composed of representatives of persons affected by homelessness crises. This body was to be consulted on the city's activities regarding the implementation of the rights enshrined in the Bill and other municipal policies affecting the homeless. In the aftermath of a shift in power following local elections that took place after the adoption of the Bill, this process was never completed. In Barcelona, on the other hand, the Bill was implemented for only two years following its adoption (2017-2018); the process involved awareness-raising workshops organised for social workers and the municipal police. Finally, Gdańsk has yet to start working on the implementation of the Bill.

Due to the limited implementation of the Homelessness Bill of Rights, the current impact of locally adopted instruments, which had been relevant to municipal policies at the time of their adoption, is either reduced (Móstoles, Barcelona) or even negligible (the Slovenian cities, Santiago de Compostela). It is too early to formulate such an assessment about Gdańsk, where the Bill has been adopted relatively recently.

\footnotetext{
${ }^{66}$ This right has been expressed as follows: 'People who are homeless should have their belongings, including tents and sleeping bags, respected by everyone including public servants. They should never be damaged or thrown away or be removed without compelling need, and if they are removed they should be made available for collection without charge'.

${ }^{67}$ This right has been expressed as follows: 'The right to life requires public authorities to take measures to preserve life. When people who are homeless (including people in emergency accommodation) die, the Council is committed to ensuring that their deaths are recorded as such, and that in each case there is a reasonably public investigation in order to understand the causes of death and what might have prevented it'.
} 
To give a full picture, it should be added that both the idea of a European model Bill (developed by non-governmental organisations) and the initiative of its adoption by individual cities (except for Santiago de Compostela) originated from local civil society organisations or, as was the case in Barcelona, from the original promoter of the Bill, FEANTSA. The best example of such an initiative is Brezdomni do Ključa, a network of Slovenian organisations working for exiting homelessness. The network, bringing together 33 non-governmental organisations from all over Slovenia, presented the concept of the Homeless Bill of Rights. Later on, members of the network took individual actions for the adoption of the Bill. The above course of action was followed in Brighton, where the idea of adopting the Bill originated from a non-governmental organisation, Brighton \& Hove Housing Coalition.

Also worthy of mention, in the context of the implementation of the Bill, is an interesting process that took place in Poland, where the idea of the Homeless Bill of Rights has gained a strong supporter: the National Human Rights Institution. At a press conference in 2018, the year of the local elections in Poland, Polish NHRI (the Ombudsman) endorsed the idea of municipal adoption and implementation of the Bill. The Ombudsman also developed and distributed a special leaflet addressing basic concerns about the concept and wording of the Bill. ${ }^{68}$

The Ombudsman's endorsement of the Bill was preceded by a request for a position statement from a nationwide umbrella organisation of non-governmental organisations working for the homeless, ${ }^{69}$ which organised a discussion on the proposed wording of the Bill. This discussion was itself preceded by consultations on the Model Homeless Bill of Rights, which involved input from persons affected by homelessness crises. During these consultations, homeless persons particularly emphasised the right guaranteed by Article $\mathrm{X}$ of the Bill, referring to their empowerment in dealings with representatives of public administration. As the homeless persons explained, the focus on that issue was a consequence of frequent assaults on their dignity by the staff of local institutions responsible for providing assistance to victims of homelessness. In this context, the consultations also called for an explicit reference to the dignity of homeless persons to be embedded in the Bill. The consulted homeless persons also highlighted the right guaranteed by Article 6 of the Bill, i.e. the right to access basic sanitary facilities, calling for an extension of its scope to include access to services for the exchange and disposal of clothing. ${ }^{70}$ Non-governmental organisations, on their

\footnotetext{
${ }^{68}$ See the leaflet Skuteczna pomoc w walce z kryzysem bezdomności, Karta Praw Osób Doświadczajacych Bezdomności-pytania i odpowiedzi [Effective Assistance in Tackling the Homelessness Crisis, the Bill of Rights of Persons Experiencing Homlessness: Q\&As] (Warsaw 2018).

${ }^{69}$ It should be added that in Poland, the obligation to provide assistance to homeless persons rests with the lowest local government unit (gmina), but is implemented mainly through non-governmental organisations.

${ }^{70}$ Intervention letter of the to Polish National Federation for Solving the Problem of Homelessness to the Ombudsman, dated 3 April 2018, unpublished.
} 
part, proposed that the Bill, conceived as a compilation of rights already guaranteed to the homeless in generally applicable laws, should also refer to specific legal acts that set out and guarantee the rights of homeless persons. Polish non-governmental organisations, noting the incompatibility of Article XI of the Bill with Polish law, pointed out that the national laws should be redrafted to abolish the criminalisation of begging. ${ }^{71}$ As later emerged, this proposal was accepted by Gdańsk.

As mentioned above, the Bill was ultimately adopted by one Polish city, Gdańsk. Another municipality, Warsaw, the nation's capital, has publicly declared an intention to adopt the instrument. ${ }^{72}$

\section{Conclusions}

Legally speaking, each Homeless Bill of Rights adopted by a European city is unquestionably a set of non-binding standards, a soft law. Out of the several aspects of the impact of the Bill as an act of soft law, three are relevant enough to be highlighted. ${ }^{73}$ First, the Bill adapts the general human rights norms enshrined in binding human rights treaties to the specific problems associated with the experience of homelessness. Second, the Bill can be a source of inspiration and an advocacy tool for non-governmental organisations working for the homeless. This is because the Bill indicates the rights afforded to homeless persons, expressing such rights in an aggregate form, in a single, accessible document. Third, it cannot be ruled out that a Bill will someday serve as a starting point for the adoption of new standards (or the development of existing standards) for the protection of the rights of persons experiencing homelessness. As was the case with the European Homeless Bill of Rights, a process of developing a soft law norm is based on experiences of persons who fall victim to infringements of particular types of rights. The knowledge thus obtained provides a foundation for further work in this area. ${ }^{74}$

${ }^{71}$ Ibid.

${ }^{72}$ The Mayor of Warsaw's response to the Ombudsman's intervention letter concerning the adoption of the Warsaw Homeless Bill or Rights, dated 13 December 2019, available online at the Ombudsman's website.

${ }^{73} \mathrm{D}$. Shelton, 'Summary', in D. Shelton (eds.), Commitment and Compliance. The Role of NonBinding Norms in the International Legal System (Oxford 2000) p. 462. On the importance of soft law standards $c f$ A.E. Boyle, 'Some Reflections on the Relationship of Treaties and Soft Law', 48(4) International \& Comparative Law Quarterly (1999) p. 901; C.M. Chinkin, 'The Challenge of Soft Law: Development and Change in International Law', International and Comparative Law Quarterly (1989) p. 850.

${ }^{74}$ On the added value of new human rights instruments $c f$ B.A. Simmons, Mobilizing for Human Rights International Law in Domestic Politics (Cambridge University Press 2009). 
The third aspect should be considered particularly relevant. Assuming that the trend of the Bill being adopted by individual cities will continue, which is likely, this process can be expected to lead to changes implemented at the level of national and international law. Moreover, this process corresponds to the efforts to strengthen the protection of the rights of the extremely poor, which have thus far culminated in the adoption of the UN Guiding Principles on Extreme Poverty and Human Rights. Notably, no further work is planned on a legally binding international agreement guaranteeing the rights of the extremely poor. The growing trend of adopting Homeless Bills of Rights highlights the need for further action in this area.

Finally, it should be noted that the process of municipal adoptions of the Bill could have a side effect, namely an increase in the level of protection of social rights, especially the right to housing, which is a crucial component of exiting homelessness. At the same time, it is worth noting that so far the Bill has been adopted by cities in countries which, at the constitutional level, guarantee the right to housing as a principle of state policy, rather than a subjective right. ${ }^{75}$ This permits the Bill to be seen as a kind of pressure to enhance the guarantee of enforcement of this right. On the other hand, this fact could explain the absence of the adoption of the Bill by cities located in jurisdictions in which the right to housing is considered a subjective right.

In any case, the discussion about adopting the Bill can contribute to breaking the negative stereotypes related to the social ills allegedly prevalent among homeless persons, such as alcohol abuse or laziness, which are harmful to the homeless community. An analysis of the process leading to the adoption of the Bill also allows us to identify and reflect on some of the basic problems associated with homelessness. Adoption of the Bill, apart from leading to the decriminalisation of homelessness, whether on a practical (law enforcement) level (as in Barcelona) or legal level (Santiago de Compostela), in some cities also brings about a future-oriented effect. In a situation characterised by likely change to municipal homeless prevention policies, a Homeless Bill of Rights can serve as an important advocacy instrument that can be used to reverse the impending change.

The case of Homeless Bill of Rights legislation can be also seen as a manifestation and confirmation of the thesis that local governments are more and more involved in the process of the protection of human rights, which is sometimes described as 'glocalisation' of human rights law. ${ }^{76}$ This is also an aspect of a

${ }^{75} \mathrm{Cf}$ Art. 78 of the Constitution of Republic of Slovenia, Art. 75(1) of the Constitution of Republic of Poland; and Section 47 of the Constitution of Spain.

${ }^{76}$ Cf M.F. Davis et al., Global Urban Justice: The Rise of Human Rights Cities (Cambridge University Press 2016); B. Oomen and E. Van den Berg, 'Human Rights Cities: Urban Actors as Pragmatic Idealistic Human Rights Users', 8 Human Rights \& International Legal Discourse (2014) p. 160. 
broader trend of engagement on the part of cities in international law and policy. ${ }^{77}$ In this context, it is worth noting that cities that are adopting homeless bills of rights are not only working towards the implementation of human rights - which seems to be a frequent occurrence in the case of the involvement of cities in human rights, without arousing controversy - but are also engaged in the generation of norms. ${ }^{78}$ By adopting the Bill, cities have taken an important step towards restoring the trust in human rights of people experiencing homelessness. The activity of cities in this field is of particular importance in view of the fact that until now the rights of the homeless have not been a key issue on the international human rights agenda.

${ }^{77} \mathrm{Cf}$ H.P. Aust, 'Shining Cities on the Hill? The Global City, Climate Change, and International Law', 26(1) The European Journal of International Law (2015) p. 255; B. Oomen and M. Baumgärtel, 'Frontier Cities: The Rise of Local Authorities as an Opportunity for International Human Rights Law', 29(2) European Journal of International Law (2018) p. 607; I.M. Porras, 'The City and International Law: In Pursuit of Sustainable Development', 36 Fordham Urban Law Journal (2006) p. 537.

${ }^{78}$ See typology of cities involvement in human rights presented in E. Durmus, 'A Typology of Local Governments' Engagement with Human Rights: Legal Pluralist Contributions to International Law and Human Rights', 38(1) Netherlands Quarterly of Human Rights (2020) p. 30. 